\section{AVALIAÇÃO DA PERSISTÊNCIA DE RESÍDUOS DE CLORPIRIFÓS NO ALIMENTO E NO MEIO AMBIENTE APÓS O CULTIVO DE COUVE-FLOR}

Evaluation Of The Persistency Of Chlorpyrifos Residues In Food And Environment After Cauliflower Cultivation

Evaluación de la persistencia de residuos de clorpirifos en el alimento y en el medio ambiente tras el cultivo de la coliflor

Ramaína Araújo de Carvalho ${ }^{1 *}$,Sara Parreiras', Vinícius de Paula Venâncio², Farah Maria Drumond Chequer ${ }^{3}$

${ }^{1}$ Faculdade de Farmácia, Universidade de Itaúna (UIT), Itaúna, MG, Brasil.

2 Departamento de Análises Clínicas, Toxicológicas e Bromatológicas, Faculdade de Ciências Farmacêuticas de Ribeirão Preto, Ribeirão Preto, SP, Brasil. ${ }^{3}$ Departamento de Análises Clínicas e Toxicológicas. Faculdade de Farmácia, Universidade Federal de Minas Gerais (UFMG), Belo Horizonte, MG, Brasil.

*E-mail: farahchequer@farmacia.ufmg.br

*E-mail: ramainacarvalho@gmail.com

\title{
RESUMO
}

O crescente desenvolvimento do setor agrícola foi devido ao crescimento populacional, que elevou o uso de praguicidas para mitigar as pragas e aumentar a disponibilidade dos alimentos. Os organofosforados representam $38 \%$ do total de praguicidas utilizados em todo o mundo, sendo o clorpirifós amplamente utilizado no Brasil; a principal fonte de contaminação ocorre pela ingestão de resíduos nos alimentos e na água para consumo. Portanto, o objetivo dese estudo foi identificar e quantificar os resíduos de clorpirifós na couve-flor, na água de poço artesiano próxima à plantação, e no solo, e comparar os resultados obtidos com o Limite Máximo de Resíduo (LMR) permitido pelo Codex Alimentarius e pela Organização Mundial de Saúde. Para tal, foi utilizada a técnica de Cromatografia Líquida de Alta Eficiência (CLAE) com detector ultravioleta (UV). Os resultados dos ensaios de persistência do praguicida clorpirifós na prática agrícola demonstraram que a aplicação nas dosagens recomendadas pelo fabricante foi segura, tendo em vista que as concentrações determinadas foram inferiores ao LMR na couve-flor e na água. $\mathrm{Na}$ amostra de solo não foram detectados resíduos de clorpirifós, confirmando que, de fato, sua degradação é rápida e sua persistência é baixa.

Palavras-chave: Praguicida. Resíduo. Organofosforado. Análise toxicológica.

\section{ABSTRACT}

The development of the agricultural sector happened due to population growth, which increased the use of pesticides to mitigate pests and increase the availability of food. Organophosphates represent $38 \%$ of all pesticides used worldwide, and chlorpyrifos is widely utilized in Brazil. The primary source of contamination by chlorpyrifos occurs by the ingestion of trace amounts of this pesticide present in food and drinking water. The aim of this study was to identify and quantify chlorpyrifos residues in cauliflower, artesian well water near the plantation, and soil, and compare the results with a maximum residue level (MRL) allowed by Codex Alimentarius and the World Health Organization. For this, we used High Performance Liquid Chromatography with UV detector. The test results of persistent chlorpyrifos in agricultural practice demonstrated that dosages used during the application recommended by the manufacturer were safe, given that the measured concentrations were below 
MRL in cauliflower and water. Chlorpyrifos residues were not detected in the soil sample, confirming its fast degradation and low persistence.

Keywords: Pesticide. Residue. Organophosphate. Toxicological analysis.

\section{RESUMEN}

El creciente desarrollo del sector agrícola se debió al crecimiento de la población, que aumentó el uso de pesticidas para mitigar las plagas y aumentar la disponibilidad de alimentos. Los organofosforados representan el $38 \%$ de los pesticidas usados en todo el mundo, siendo los clorpirifos ampliamente utilizados en Brasil. La principal fuente de contaminación se produce por la ingestión de pequeñas cantidades en los alimentos y el agua potable. Por lo tanto, el objetivo de este estudio fue identificar y cuantificar los residuos de clorpirifos en la coliflor, en el agua del pozo artesiano próximo a la plantación, y en el suelo, y comparar los resultados con el límite de residuos (LMR) permitidos por el Codex Alimentarius y la Organización Mundial de la Salud. Para ello, se utiliza la técnica de cromatografía líquida de alta eficiencia (HPLC) con detector ultravioleta (UV). Los resultados de los ensayos de persistencia del pesticida clorpirifos en la práctica agrícola demostraron que la aplicación en las dosis recomendadas por el fabricante fue segura, teniendo en cuenta que las concentraciones determinadas fueron inferiores al LMR en la coliflor y en el agua. En la muestra de suelo no fueron detectados residuos de clorpirifos, confirmando que, de hecho, su degradación es rápida y su persistencia es baja.

Palabras clave: Plaguicidas. Residuo. Organofosforados. Análisis toxicológico.

\section{INTRODUCTION}

The increasing demand for food, due to population growth, was the responsible for the exacerbated use of pesticides in plant foods to compensate losses in the cultivation related to pest infestation. The global market for pesticides grew by $93 \%$ over the past decade, while the Brazilian market grew 190\% ${ }^{(1,2)}$. In 2009, Brazil reached the position of world's largest pesticide consumer, reaching the average annual consumption of $5.2 \mathrm{~kg}$ of pesticides per capita ${ }^{(3)}$.

To both assess and promote food quality regarding the use of pesticides, the Brazilian health surveillance agency ANVISA (Agência Nacional de Vigilância Sanitária) created in 2011 a program called Program for pesticide residue analysis in food PARA (Programa de análise de resíduos de agrotóxicos em alimentos). The objective of this program is to analyze the pesticide residues in plant foods, contributing to the food security and preventing acute or chronic poisoning that may result from improper exposure to pesticides by the $\operatorname{diet}^{(4)}$.

Chlorpyrifos, an organophosphate classified as class II "highly toxic", is abroad-spectrumacaricide and insecticide, highly efficient and used around the world. Due to its low cost and its effectiveness against many pest species, this compound is one of the most used pesticides in Brazil. Under indiscriminately application conditions, it may cause contamination of soil and water resources, with high risk to public health and the fauna and flora ${ }^{(5-8)}$.

Human exposure to chlorpyrifos can occur by dermal, oral and pulmonary routes, and the exposure of low concentrations of this compound by the diet is considered to be the primary non-occupational source of exposure ${ }^{(9)}$.

When compared with other organophosphates, chlorpyrifos can be stable and persistent in the environment and is widely use throughout the world. It can cause toxic effects on non-target organisms, especially mammals, due to its primary neurotoxic action: inhibition of acetyl cholinesterase, which leads to acetylcholine accumulation in the nerve endings ${ }^{(10,11)}$. 
Many experimental studies have demonstrated both neurotoxic and behavioral effects after exposure to low levels of chlorpyrifos, such as cognitive deficits, reproductive toxicity, teratogenicity, immunological abnormalities, development defects and low birth weight newborns ${ }^{(12-17)}$.

In India, residues of chlorpyrifos were detected in breast milk samples from mothers previously exposed to pesticides. The presence of chlorpyrifos in the breast milk was related to the neurological problems these children experienced, considering that the contaminated breast milk was their primary food source ${ }^{(18)}$.

Because of the toxicity of pesticides to humans, regulatory agencies establish maximum residue levels (MRLs) permitted to be detected in food, considering the waiting period (time between the last application of the pesticide and harvesting the crop). In Brazil, these levels were established by PARA. As chlorpyrifosis consistently used in the country, the analysis and monitoring of food, water and soil are fundamental to safeguard human health and the environment.

The aims of this study were to evaluate the chlorpyrifos residues in cauliflower samples, in water from an artisan well near the planting site and soil where this vegetable was cultivated, in an agricultural area in the Southeast area of Minas Gerais. Also, we aimed at verifying whether the measured concentrations are within the MRL for each sample, considering the 21 day waiting time for this pesticide.

\section{MATERIAL AND METHODS}

\subsection{Chemicals}

The analytical standard Chlorpyrifos was obtained from the commercially available formulation Lorsban 480 BR (Dow Agrosciences, Midland, MI, USA), which composition consists of $48 \%$ (w/v) Chlorpyrifos.

Chlorpyrifos has IUPAC (International Union of Pure and Applied Chemistry) name of O,O-Diethyl O-3,5,6-trichloropyridin2-yl phosphorothioate.

\subsection{Field study}

The experiments were performed on a farm of the Southeast region of Minas Gerais, Brazil. The crops were pulverized with diluted Chlorpyrifos (150 mL of the commercially available pesticide in $90 \mathrm{~L}$ of water) every two weeks until the cauliflowers were grown. Cauliflower, soil, and water samples were collected after 21 days waiting period.

\subsection{Sample collection and preparation}

Cauliflower, soil and water sample collection and analysis were performed by Hidrocepe Serviços de Qualidade Ltda. Samples were collected after the 21 days waiting period for this pesticide and transported at $4{ }^{\circ} \mathrm{C}$, protected from light.

After random sampling procedures, two samples of cauliflower, two kilograms of soil $(25 \mathrm{~cm}$ deep) and one liter of water were collected. The water sample was collected in amber glass bottles and kept at $21.4{ }^{\circ} \mathrm{C}$ and pH 6.0 . Both flask and lid were rinsed in the sample water for six times and closed immediately after the sampling procedure was performed. The cauliflower and soil samples were processed and stored at $-20^{\circ} \mathrm{C}$. The water sample was kept at $4{ }^{\circ} \mathrm{C}$ until analysis.

The sample preparation was performed according to Zenebon, et al. ${ }^{(19)}$. Briefly, the cauliflower samples were washed, and the edible parts were separated. These pieces were homogenized in a multiprocessor. 50 mg samples were used for the 
determinations. $50 \mathrm{mg}$ of soil samples were pulverized in a mortar and pestle and passed through a strainer (144 holes/ $\left./ \mathrm{cm}^{2}\right)$. Cauliflower and soil were sampled by quartering. $1 \mathrm{~mL}$ of water sample was utilized for the analysis.

Chlorpyrifos was extracted from the samples using acetone and chloroform. From the organic phase of each sample, $1 \mathrm{~mL}$ was injected in the equipment (chromatograph). All analyses were performed in duplicate.

\subsection{Equipment and chromatographic determinations}

In this study, we have used a high performance liquid chromatography equipment (Agilent, model 1120 Compact LC), equipped with UV-Vis detector. The conditions used for the chlorpyrifos determination was: $C_{18}$ Zorbax ODS column ( $4.6 \mathrm{~mm} x$ $250 \mathrm{~mm}, 5 \mu \mathrm{m})$; mobile phase acetonitrile: water $(76: 24 \mathrm{v} / \mathrm{v}) ; 0.7 \mathrm{~mL} / \mathrm{min}$ flow; $245 \mathrm{~nm}$ wavelength and $20 \mu \mathrm{L}$ injection volume; run time: 30 minutes; Limit of detection: $0.2 \mathrm{ppb}$ and limit of quantification $0.25 \mathrm{ppb}$.

The residual concentrations of chlorpyrifos in samples were calculated by the calibration factor (standard concentration divided by the standard area) using a $3.29 \mathrm{mg} \mathrm{kg}^{-1}$ chlorpyrifos standard solution.

\section{RESULTS AND DISCUSSION}

The place chosen for the experiments was a countryside area in the Southeast Minas Gerais, responsible for the majority of the cauliflower supplies of Ceasa-MG, in Belo Horizonte. This location provides $31.6 \%$ of the total cauliflower supply of that unit(20).

\subsection{Chlorpyrifos residual level detection}

The samples were analyzed by the same chromatographic method as the standard and the chlorpyrifos retention time was compared. The retention time and area of this standard solution are shown in Table 1. The calibration factor was used to calculate the concentration of these pesticides in the samples. No peak at the same retention time as chlorpyrifos standard was observed in the soil samples.

\subsection{Cauliflower samples}

The cauliflower samples showed average chlorpyrifos concentration of $3.31 \mathrm{\mu g} \mathrm{kg}^{-1}$, which is lower than the Maximum Residue Level (MRL) for this vegetable, according to regulatory agencies ${ }^{(21)}$. The results are shown in Table 2.

Other authors also showed the same pattern for this pesticide in cauliflower samples. Lozowicka, Jankowska and Kaczynski ${ }^{(22)}$ analyzed 365 samples of different vegetables harvested from the northeastern Poland and, between 97 cauliflower samples, only 04 of them showed chlorpyrifos residues, ranging between 5 and $16 \mu \mathrm{kg}^{-1}$.

Five determinations performed in the United Kingdom used chlorpyrifos $(0.96 \mathrm{~kg} / \mathrm{hectare}$ with 21 days waiting period) and the concentrations found for this pesticide were lower than $10 \mu \mathrm{g} \mathrm{kg}^{-1}$ for three determinations, and $10 \mu \mathrm{g} \mathrm{kg}^{-1} \mathrm{and} 20 \mu \mathrm{g}$ $\mathrm{kg}^{-1}$ for the other two assays ${ }^{(23)}$.

Studies performed in the Shaanxi Province also did not detect chlorpyrifos in any of the 16 cauliflower samples analyzed ${ }^{(24)}$. Another study conducted in the Zhejiang Province analyzed 52 cauliflowers samples, and none of them had substantial amounts of chlorpyrifos ${ }^{(25)}$. The present study, however, utilized a high sensitivity method, with a lower limit of quantification than the Chinese studies ( 5 and $10 \mu \mathrm{g} \mathrm{kg}^{-1}$ from the studies versus $0.2 \mathrm{\mu g} \mathrm{kg}^{-1}$ for this study). 
Another study performed in India with okra crops treated with a single dose of chlorpyrifos (200 mg/hectare) or two doses (400 mg/hectare) showed initial residual concentrations of 67 and $129 \mu \mathrm{g} \mathrm{kg}^{-1}$ respectively (above MRL). However, after seven and fifteen days of treatment with the pesticide, the levels of chlorpyrifos were lower than the limit of detection $\left(10 \mu \mathrm{g} \mathrm{kg}^{-1}\right)^{(26)}$.

Rani, Saini and Kumari(27) published similar observation, whose observed that the concentration of chlorpyrifos was below MRL since the first day after its use in tomato crops.

\subsection{Water samples}

The water samples showed average $3.8 \mu \mathrm{g} \mathrm{kg}$ - $^{-1}$ of chlorpyrifos, which is lower than the reference concentration for drinking water which is $30 \mathrm{gg} \mathrm{L}^{-1(28)}$. All data are shown in Table 2.

Studies performed in Nanjing and Guangxi Provinces showed no detectable residue of chlorpyrifos after 21 days waiting period for water samples ${ }^{(29)}$.

Data from Environmental Protect Agency (US EPA)(30) showed chlorpyrifos concentrations below $0.1 \mu \mathrm{g} \mathrm{L}^{-1}$ and $0.4 \mu \mathrm{g} \mathrm{L}^{-1}$ maximum.

According to the database from the Washington Department of Ecology's Environmental Information Management (WAEIM), superficial water was monitored between 2002 and 2011 in Salmonid-Bearing Streams area and 95\% of the samples showed chlorpyrifos concentrations ranging from 0.033 to $0.3 \mu \mathrm{g} \mathrm{kg}{ }^{-1}$ and maximum levels between 0.35 and $0.59 \mu \mathrm{g} \mathrm{kg}{ }^{-1}$. The National Center for Water Quality Research reported chlorpyrifos in six samples from ten different stations in Lake Erie Basin and Ohio, which concentrations were 0.002 and $0.37 \mu \mathrm{g} \mathrm{kg}^{-1(31)}$.

In 2009 in Brazil, Instituto de Tecnologia de Pernambuco collected and analyzed 10 water samples from wells in the Chapada Apodi area (between Ceará and Rio Grande do Norte) and didn't detect chlorpyrifos in any samples ${ }^{(32)}$.

Between 1995 and 1997, water samples from the Honduras hydrographic basin regarding pesticides residues at three different locations: Choluteca, Zamoro and La Lima. Chlorpyrifos was detected in river samples from all three areas $\left(30 \mu \mathrm{g} \mathrm{kg}^{-1}\right)$. Samples from lakes and wells showed $60 \mu \mathrm{g} \mathrm{kg}^{-1}$ and $100 \mu \mathrm{g} \mathrm{kg}^{-1}$ of chlorpyrifos in Zamoro and La Lima areas, respectively ${ }^{(33)}$.

Studies showed chlorpyrifos, even in low concentrations in water, can be highly neurotoxic to fish species, since there are evidence this pesticide can change their swim mode, visual and sensory functions, which can lead to death if in high concentrations ${ }^{(34,35)}$.

\subsection{Soil samples}

Chlorpyrifos and other modern pesticides were projected to be degradable and have low environmental persistence, while the first generation pesticides had higher degradation and ecological persistence (up to several years). In plants, water and soil, the chlorpyrifos degradation involves the cleavage of the ester group, producing 3,5,6-trichloro-piridinol (TCP), which is the primary degradation product for this pesticide. TCP is considered toxicologically insignificant since it doesn't have the same pesticide activities as the original compound(36).

A study performed in lowa (USA) demonstrated that after 12 weeks of utilization, only 3.8\% of the initial dose of chlorpyrifos $\left(10 \mathrm{mg} \mathrm{kg}^{-1}\right)$ was detected in soil, being TCP responsible for $63 \%$ of this concentration and carbon dioxide $\left(\mathrm{CO}_{2}\right)$ responsible for $17 \%{ }^{(37)}$.

No chlorpyrifos residue was detected in the soil samples analyzed in this study (Table 2) since the degradation of this pesticide involves its metabolism in the soil in one to four weeks. This information corroborates investigations previously performed in Illinois, Michigan and California were no chlorpyrifos residues were found in soil samples (30 cm deep) after one year of crop cultivation ${ }^{(37)}$. 
A half-life of dissipation of 2.2 days was reported after spraying chlorpyrifos in rice bays(37). Fang et al. ${ }^{(8)}$ reported $98.7 \%$ dissipation of chlorpyrifos in greenhouse soil after 25 days (in the summer), and the half-life for this compound was 0.6 to 1.2 days.

Rani, Saini and Kumari(27) studied the chlorpyrifos persistence after tomato cultivation and no residues were detected 5 and 10 days after its use (single and double dose, respectively). Another study, performed in China in Nanjing and Guangxi provinces also showed the residues of chlorpyrifos in soil were undetectable under all application levels and frequencies after 28 days of application ${ }^{(29)}$.

Kammerbauer and Moncada( ${ }^{(33)}$ found chlorpyrifos concentrations below $10 \mu \mathrm{g} \mathrm{kg}^{-1}$ in soil samples from two different agricultural areas in Honduras: Zamorano and La Lima.

Another study performed in 2013 in the Nanjing province (China) reported concentrations of $2.2 \mathrm{mg} \mathrm{kg}^{-1}$ of chlorpyrifos 21 days after this pesticide was used at $0.97 \mathrm{~kg} /$ hectare $^{(38)}$.

Also, a reduction in the nematodes and earthworms biomass that live in soil has been reported as a result of the decline in the activity of acetyl cholinesterase, growth, reproduction and development of these organisms, all caused by chlorpyrifos exposition. This fact characterizes an environmental damage, since the chlorpyrifos exposition changes the microbial activity of the soil, increasing the biodegradation period for this pesticide, especially at mild temperatures ${ }^{(39,40)}$.

Additionally, bees have been reported as chlorpyrifos targets. This pesticide showed to increase these animals death rate and to cause honey contamination ${ }^{(41)}$.

\section{CONCLUSION}

The results of the field experiments have shown that chlorpyrifos application within the standards, allows it to be detected in concentrations allowed for exposure to humans. As presented in this study, the detection of pesticides at levels below the MRL in cauliflower and water and the absence of residues in the soil after 21 days waiting period confirms that this compound degradation is faster and its persistence is lower when compared to organochlorines.

Therefore, monitoring chlorpyrifos residues should be consistently performed to prevent and reduce risks to human health and the environment. It also ensures that people are not get exposing to this pesticide by food or water intake. Additionally, this also prevents contamination of soil, groundwater and the plantation sites.

\section{ACKNOWLEDGEMENTS}

The authors thank the University of Itaúna, Brazil, and Fundação de Amparo à Pesquisa do Estado de Minas Gerais (FAPEMIG), for their financial support.

\section{REFERENCES}

1. GAMA A, OLIVEIRA A, CAVALCANTE R. Inventário de agrotóxicos e risco de contaminação química dos recursos hídricos no semiárido cearense. Química Nova. 2013; 36(3): 462-7.

2. BRASIL. Seminário volta a discutir mercado de agrotóxicos em 2012 Brasília: Agência Nacional de Vigilância Sanitária; 2012 [cited 2015 mar]. Available from: http://portal.anvisa.gov.br/wps/content/anvisa+portal/anvisa/sala+de+imprensa/ menu++noticias+anos/2012+noticias/seminario+volta+a+discutir+mercado+de+agrotoxicos+em+2012 
3. LONDRES F. Por que campeão de agrotóxicos. In: Londres F, editor. Agrotóxicos no Brasil um guia para ação em defesa da vida. Rio de Janeiro: AS-PTA; 2011, cap. 1, p. 17-24. [cited 2015 mar]. Available from: http://aspta.org.br/wp-content/ uploads/2011/09/Agrotoxicos-no-Brasil-mobile.pdf

4. ANVISA. Programa de análise de resíduos de agrotóxicos em alimentos (PARA): Relatório complementar relativo à segunda etapa das análises de amostras coletadas em 2012. Brasília, 2012 [cited 2015 mar]. Available from: http://portal.anvisa. gov.br/wps/wcm/connect/d67107004634368583a5bfec1b28f937/Relat\%C3\%B3rio+PARA+2012+2\%C2\%AA+Etapa++17_10_14-Final.pdf?MOD=AJPERES

5. ANVISA. C20 Clorpirifós. Brasilia, 2015 [cited 2015 mar].

6. CHEN W, ZANG Y, YUAN L, LI T, J L. Neurobehavioral evaluation of adolescent male rats following repeated exposure to chlorpyrifos. Neurosci Lett. 2014; 570: 76-80.

7. SOUZA T. Remoção de inseticida clorpirifós em sistemas alagados construídos cultivados com diferentes espécies vegetais, em Viçosa/MG. Viçosa: Faculdade de Engenharia Agrícola/UFV; 2013.

8. FANG H, YU YL, WANG X, SHAN M, WU XM, YU JQ. Dissipation of chlorpyrifos in pakchoi-vegetated soil in a greenhouse. J Environ Sci (China). 2006; 18(4): 760-4.

9. EATON D, DAROFF R, AUTRUP H, BRIDGES J, BUFFLER P, COSTA L, ET AL. Review of the toxicology of chlorpyrifos with an emphasis on human exposure and neurodevelopment. Crit RevToxicol. 2008; 2(1-125).

10. BAIG S, AKHTERA N, ASHFAQ M, ASI M. Determination of the Organophosphorus Pesticide in Vegetables by HighPerformance Liquid Chromatography. Am Eurasian J Agric Environ Sci. 2009; 6(5): 513-9.

11. ALONZO H, CORRÊA C. Praguicidas. In: Oga S, Camargo M, Batistuzzo J, editors. Fundamentos de Toxicologia. São Paulo: Atheneu; 2008. p. 621-40.

12. SHITTU M, AMBALI S, AYO J, FATIHU M, SULAIMAN M, YAQUB L. Evaluation of chronic chlorpyrifos-induced reproductive toxicity in male wistar rat: protective effects of vitamin C. J ExplntegrMed. 2013; 3(1): 23-30.

13. UZUN FG, KALENDER Y. Chlorpyrifos induced hepatotoxic and hematologic changes in rats: the role of quercetin and catechin. Food Chem Toxicol. 2013; 55: 549-56.

14. UCHENDU C, AMBALI S, AYO J. The organophosphate, chlorpyrifos, oxidative stress and the role of some antioxidants: A review. Afr J Agric Res. 2012; 7(18): 2720-8.

15. AKTAR N, SRIVASTANA M, RAIZADA R. Transplacental disposition and teratogenic effects of chlorpyrifos in rats. JToxicol Sci 2006; 32(5): 521-7.

16. ZHAO Q, DOURSON M, GADAGBUI B. A review of the reference dose for chlorpyrifos. Regul Toxicol Pharmacol. 2006; 44(2): $111-24$.

17. MOSER VC, PHILLIPS PM, MCDANIEL KL, MARSHALL RS, HUNTER DL, PADILLA S. Neurobehavioral effects of chronic dietary and repeated high-level spike exposure to chlorpyrifos in rats. Toxicol Sci. 2005; 86(2): 375-86.

18. BEDI JS, GILL JP, AULAKH RS, KAUR P, SHARMA A, POONI PA. Pesticide residues in human breast milk: risk assessment for infants from Punjab, India. Sci Total Environ. 2013;463-464:720-6.

19. ZENEBON O, PASCUET N, TIGLEA P. Métodos físico-químicos para análise de alimentos São Paulo: Instituto Adolfo Lutz; 2008 [cited 2015 mar]. Available from: http://wp.ufpel.edu.br/nutricaobromatologia/files/2013/07/NormasADOLFOLUTZ.pdf 
20. MINAS GERAIS. Ceasa Minas Unidade Grande BH. Acompanhamento dos Produtos Ofertados por Procedência - Estado/ Município em 2013. [cited 2015 mar]. Available from: http://www.ceasaminas.com.br/informacoesmercadogeral.asp

21. CODEX ALIMENTARIUS. Pesticides Residues in Food and Feed: Maximum residues Limits for Chlorpirifos 2003 [cited 2015 mar]. Available from: http://www.codexalimentarius.net/pestres/data/pesticides/details.html?id=17

22. LOZOWICKA B, JANKOWSKA M, KACZYNSKI P. Pesticide residues in Brassica vegetables and exposure assessment of consumers. Food Control. 2012; 25(2): 561-75.

23. FAOMHO. Pesticides residues in food 2000: Joint FAOMHO Metting on Pesticide Residues 2000 [cited 2015 mar]. $f$

24. WANG S, WANG Z, ZHANG Y, WANG J, GUO R. Pesticide residues in market foods in Shaanxi Province of China in 2010. Food Chem. 2013; 138(2-3): 2016-25.

25. YUAN Y, CHEN C, ZHENG C, WANG X, YANG G, WANG Q, ET AL. Residue of chorpyrifos and cypermethrin in vegetables and probabilistic exposure assessment for consumers in Zhejiang Province, China. Food Control 2014; 36: 63-8.

26. SAMRITI, CHAUHAN R, KUMARI B. Persistence and Effect of Processing on Reduction of Chlorpyriphos Residues in Okra Fruits Bull. Environ Contam Toxicol. 2011; 87(2): 198-201.

27. RANI M, SAINI S, KUMARI B. Persistence and effect of processing on chlorpyriphos residues in tomato (Lycopersicone sculantum Mill). Ecotoxicol Environ Saf. 2013; 95: 247-52.

28. WHO. Chlorpyrifos in Drinking-water: Background document for development of WHO Guidelines for Drinking-water Quality 2004 [cited 2015 mar]. Available from: http://www.who.int/water_sanitation_health/dwq/chemicals/chlorpyrifos. pdf

29. ZHANG X, SHEN Y, YU X, LIU X. Dissipation of chlorpyrifos and residue analysis in rice, soil and water under paddy field conditions. Ecotoxicol Environ Saf. 2012; 78: 276-80.

30. EPA US. Drinking water assessment of chlorpyrifos. Washington, DC: Office of Prevention, Pesticides and Toxic Substances; 1998.

31. WILLIAMS W, GIDDINGS J, PURDY J, SOLOMON K, GIESY J. Exposures of Aquatic Organisms to the Organophosphorus Inseticide, Chlorpyrifos Resulting from use in the United States. In: Giesy J, Solomon K, editors. Reviews of Environmental Contamination and Toxicology: Ecological Risk Assessment for Chlorpyrifos in Terrestrial and Aquatic Systems in the United States. 2014, 231v., 282p. [cited 2015 mar]. Available: http://ink.springer.com/book/10.10\%2007/978-3-319-03865-0

32. PLANO DE GESTÃO PARTICIPATIVA DOS AQUífEROS DA BACIA POTIGUAR: Estado do Ceará. Fortaleza, 2010.

33. KAMMERBAUER J, MONCADA J. Pesticide residue assessment in three selected agricultural production systems in the Choluteca River Basin of Honduras. Environ Pollut. 1998; 103(2-3): 171-81.

34. MISHRA A, DEVI Y. Histopathological alterations in the brain (optic tectum) of the fresh water teleost Channa punctatus in response to acute and subchronic exposure to the pesticide Chlorpyrifos. Acta Histochem. 2014; 116(1): 176-81.

35. DE SILVA PM, SAMAYAWARDHENA LA. Low concentrations of lorsban in water result in far reaching behavioral and histological effects in early life stages in guppy. Ecotoxicol Environ Saf. 2002; 53(2): 248-54.

36. RACKE KD. Environmental fate of chlorpyrifos. Rev Environ Contam Toxicol. 1993; 131: 1-150. 
37. AUSTRALIA. The NRA for Chlorpyrifos - Environmental Assessment 2015 [cited 2015 mar]. Available from: http://apvma. gov.au/sites/default/files/chlorpyrifos-phase-5-interim-review-report-environmental_0.pdf

38. LU MX, JIANG WW, WANG JL, JIAN Q, SHEN Y, LIU XJ, et al. Persistence and dissipation of chlorpyrifos in Brassica chinensis, lettuce, celery, asparagus lettuce, eggplant, and pepper in a greenhouse. PLoS One. 2014; 9(6): e100556.

39. DE SILVA PM, PATHIRATNE A, VAN STRAALEN NM, VAN GESTEL CA. Chlorpyrifos causes decreased organic matter decomposition by suppressing earthworm and termite communities in tropical soil. Environ Pollut. 2010; 158(10): 3041-7.

40. ROH JY, CHOI J. Ecotoxicological evaluation of chlorpyrifos exposure on the nematode Caenorhabditis elegans. Ecotoxicol Environ Saf. 2008; 71(2): 483-9.

41. CARRASCO-LETELIER L, MENDOZA-SPINA Y, BRANCHICCELA MB. Acute contact toxicity test of insecticides (Cipermetrina 25, Lorsban 48E, Thionex 35) on honeybees in the southwestern zone of Uruguay. Chemosphere. 2012; 88(4): 439-44. 